\title{
Angel Kwolek-Folland
}

\section{Gender, the Service Sector, and U.S. Business History}

Despite the importance of service-sector activities, both to women and to the U.S. economy, services have not figured prominently in business history. A consideration of the usefulness of this subject to business history is followed by a case study of "household services" in the nineteenth century, showing their social and economic value and the ways in which they exemplified the integral relations between women's work and business.

B y now, U.S. business historians are familiar with gender as a category of analysis. Whereas, in Europe, gendered analysis of business history is relatively new, at least one synthetic treatment and two special journal issues on gender and business history have been published in the United States. ${ }^{1}$ Given the greater number and higher level of sophistication of publications on the subject in the 1990s, the field could be said to have "arrived" in the United States, even though it is not yet fully developed. As Margaret Walsh and I note in the introduction to this issue, the concept of "services" is derived from assigning an economic value to certain basic social needs and relations: scraping out the dirt produced by daily life, finding a room for a tired traveler, answering a question, feeding the hungry, comforting the sick. We could not exist without these services, and increasingly we pay to have them performed.

ANGEL KWOLEK-FOLLAND is professor of history and women's studies and Interim Associate Provost for Academic Affairs at the University of Florida.

${ }^{1}$ Angel Kwolek-Folland, Incorporating Women: A History of Women and Business in the United States (New York, 2002); Enterprise \& Society 2 (special issue on gender and business) (Mar. 2001); and Business History Review 72 (special issue) (Summer 1998). Mary Yeager recently compiled and edited a comprehensive three-volume set of previouslypublished articles on women in business history, Women in Business (Cheltenham, 1999). In her insightful review of the collection, Katrina Honeyman noted that "almost two-thirds of the 57 articles ponder American issues." Katrina Honeyman, "Engendering Enterprise," Business History 43 (Jan. 2001): 119-26. See also Robert Beachy, Béatrice Craig, and Alastair Owens, eds., Women, Business, and Finance in Nineteenth-Century Europe: Rethinking Separate Spheres (Oxford, 2006).

Business History Review 81 (Autumn 2007): 429-450. (C) 2007 by The President and Fellows of Harvard College. 


\section{Angel Kwolek-Folland / 430}

Historically, women's entrepreneurship, production, and labor has been confined to the service occupations. ${ }^{2}$ Women's domination of this sector began with the development of services as a part of the U.S. national economy in the late eighteenth century: first in domestic work and personal services, such as nursing, millinery, dressmaking, and hairdressing; then, in the nineteenth century, in clerical work and retailing. In the United States, as in the industrialized nations generally, the history of the service sector parallels the history of women's participation in the labor force and their entrepreneurial engagement. ${ }^{3}$ Between $195^{\circ}$ and 1990, as the United States became a service society, the largest proportion of new service workers in every sector was female. ${ }^{4}$ Further, despite the passage of numerous laws outlawing discrimination on the basis of sex in the United States during the 1960s and 1970s, occupational sex segregation continues. ${ }^{5}$ In addition, when women enter a new field as workers, managers, or proprietors, both the skill content and the social status of the occupation are downgraded as the field becomes "feminized." This process of depreciation has been described by contemporary businesswomen whose autobiographies suggest that modern female executives and professionals inhabit an environment that is still strongly shaped by ideas about domestic labor and services. ${ }^{7}$

Despite their importance, both to women and to the economy, however, services have not figured prominently in treatments of gender by

\footnotetext{
${ }^{2}$ See the introduction to this issue for a discussion of the definition and gendered nature of the service industries. On occupational sex segregation, see Jo Anne Preston, "Occupational Gender Segregation: Trends and Explanations," Quarterly Review of Economics and Finance 39 (Dec. 31, 1999): 611-24; Lisa B. Meyer, "Economic Globalization and Women's Status in the Labor Market: A Cross-National Investigation of Occupational Sex Segregation and Inequality," Sociological Quarterly 44 (Summer 2004): 352-84; and Richard Anker, "Theories of Occupational Segregation by Sex: An Overview," in Women, Gender and Work: What is Equality and How Do We Get There? ed. Martha Fetherolf Loutfi (Geneva, 2001) $129-56$.

${ }^{3}$ Kwolek-Folland, Incorporating Women; Alice Kessler-Harris, Out to Work: A History of Wage-Earning Women in the United States (New York, 1982); Teresa Amott and Julie Matthaei, Race, Gender, and Work: A Multicultural Economic History of Women in the United States (Boston, 1991); and Dorothy Sue Cobble, Dishing It Out: Waitresses and Their Unions in the Twentieth Century (Urbana, Ill., 1991).

${ }^{4}$ Thomas L. Steiger and Mark Wardell, "Gender and Employment in the Service Sector," Social Problems 42 (Feb. 1995): 91-124; Joachim Singelmann and Marta Tienda, "The Process of Occupational Change in a Service Industry: The Case of the United States, 19601980," in New Approaches to Economic Life, eds. Bryan Roberts, Ruth Finnegan, and Duncan Gallie (Manchester, U.K., 1985), 48-67.

${ }^{5}$ Changes in federal law (the 1963 Equal Pay Act, the Civil Rights Act of 1964, and Executive Order 11375 mandating affirmative-action strategies in federal contracting procurement) led all states to outlaw sex discrimination by 1975 . See Steger and Wardell, "Gender and Employment in the Service Sector," 93

${ }^{6}$ Judy Wajcman, "Patriarchy, Technology, and Conceptions of Skill," Work and Occupations 18, no. 1 (1991): 29-45.

${ }^{7}$ See, for example, Carly Fiorina, Tough Choices: A Memoir (New York, 2006).
} 
business historians. There are several reasons for this neglect. Most discussions of the tertiary sector by economic and business historians overlook women's presence and thus ignore the implications of that presence for business and for women themselves. ${ }^{8}$ Business historians find it difficult to place many services-such as sex work, domestic labor, or home-based manufacturing-into traditional business history categories, such as the firm, entrepreneurs, or infrastructure development. In some cases, historical research is cordoned off and channeled into different fields, leading to the loss of useful perspectives on gender and the service sector. Labor history and the history of consumption are probably the best examples of historical fields with deep material connections to the history of business and the service sector in particular, but they are not always regarded as belonging to business history. ${ }^{9}$

Added to the disciplinary divisions are difficulties with the available data. In the United States, federal and state census data form the backbone of much of the research on the modern economy, particularly analyses of women's workforce participation, and the categorization of these data reinforces the division of the economy into sectors. Connecting the service sector to women's household labor creates an ambiguous and usually unexamined correlation between services and domesticity. Scholars of women's modern economic history have emphasized labor and the changing demography of wage earning. They have noted the many flaws in census data, including the ways that information is categorized, and they have pointed out the use of questionable techniques in finding and "correcting" errors in the data. ${ }^{10}$ Even more problematic, however, is the fact that the construction of the census, beginning with its first assumptions, is premised on neoclassical economic theory based on separate spheres. U.S. census data, indeed most census data, construct the economy as a gendered, hierarchical public-private dichotomy. The census has not only obscured women's economic activities and

\footnotetext{
${ }^{8}$ Marianne A. Ferber and Julie A. Nelson, eds., Beyond Economic Man: Feminist Theory and Economics (Chicago, 1993).

${ }^{9}$ For example, works such as Cindy Sondik Aron's Ladies and Gentlemen of the Civil Service: Middle-Class Workers in Victorian America (New York, 1987); Susan Porter Benson's Counter Cultures: Saleswomen, Managers, and Customers in American Department Stores, 1890-1940 (Urbana, Ill., 1988); and David Katzman's Seven Days a Week: Women and Domestic Service in Industrializing America (Urbana, Ill., 1978) address corporate business structure, consumerism and retail sales, and the assumptions underlying entrepreneurship and self-employment, yet all are usually characterized as "labor history."

${ }^{10}$ Claudia Goldin, Understanding the Gender Gap: An Economic History of American Women (New York, 1990), especially the appendix to ch. 2; Margo A. Conk, "Accuracy, Efficiency, and Bias: The Interpretation of Women's Work in the U.S. Census of Occupations, 1890-1940," Historical Methods 14 (Spring 1981): 65-72; and Joan W. Scott, "A Statistical Representation of Work: La Statistique de l'industrie à Paris, 1847-1848," in Gender and the Politics of History (New York, 1988), 13-38.
} 
the layered divisions of class and race; it has also reinforced the virtual invisibility of women in the narrative of modern history. By bringing the gendered nature of the service sector into focus, it is possible to connect business history to other historical frameworks, such as labor and legal history. ${ }^{11}$

\section{Comprehensive Histories}

Most of the materials published on U.S. gender and business history since 2000 augment areas clearly within the purview of business history: autobiographies and biographies of businesswomen, histories of the firm, entrepreneurship, small business and independent proprietors, and consumerism. ${ }^{12}$ Many of these are superb and valuable studies. Patricia Cleary's biography of Elizabeth Murray, Nikki Mandell's study of corporate welfare, and Daniel Hill's work on advertising and women all are situated within business history while introducing gender as a main theme. ${ }^{13} \mathrm{~A}$ few scholars explore masculinity, or men as men, in business. ${ }^{14}$ Others-like Susan Lewis and Edith Sparks, who have conducted

${ }^{11}$ Kwolek-Folland, Incorporating Women, esp. p. 5.

${ }^{12}$ On businesswomen, see Virginia G. Drachman, Enterprising Women: 250 Years of American Business [exhibition catalogue] (Chapel Hill, 2002); Jane R. Plitt, Martha Matilda Harper and the American Dream: How One Woman Changed the Face of Modern Business (Syracuse, 200o); and Mary Yeager, "Mavericks and Mavens of Business History: Miriam Beard and Henrietta Larson," Enterprise \& Society 2 (Dec. 2001): 687-768. On entrepreneurship and small businesses, see Robert L. Boyd, "Race, Labor Market Disadvantage, and Survivalist Entrepreneurship: Black Women in the Urban North during the Great Depression," Sociological Forum 15 (Dec. 2000): 647-70; Melissa Fisher, "Wall Street Women: Navigating Gendered Networks in the New Economy," Frontiers of Capital: Ethnographic Reflections on the New Economy, eds. Melissa Fisher and Greg Downey (Durham, N.C., 2006), 209-36; Susan Hay, ed., From Paris to Providence: Fashion, Art, and the Tirocchi Dressmakers' Shop, 1915-1947 [exhibition catalogue] (Providence, R.I., 2000); Debra Michals, "Beyond 'Pin Money': The Rise of Women's Small Business Ownership, 1945-1980," Ph.D. diss., New York University, 2002; Kimberly L. Reed, Managing Our Margins: Women Entrepreneurs in Suburbia (New York, 2001); Linda L. Sturtz, Within Her Power: Propertied Women in Colonial Virginia (New York, 2002).

On consumerism, see Regina Blaszczyk, Imagining Consumers: Design and Innovation from Wedgwood to Corning (Baltimore, 200o); Lizabeth Cohen, A Consumer's Republic: The Politics of Mass Consumption in Postwar America (New York, 2003); Janice Williams Rutherford, Selling Mrs. Consumer: Christine Frederick and the Rise of Household Efficiency (Athens, Ga., 2003); Nancy Owen, Rookwood and the Industry of Art: Women, Culture and Commerce, 1880-1913 (Columbus, Oh., 2001); Philip Scranton, ed., Beauty and Business: Commerce, Gender, and Culture in Modern America (New York, 200o); Landon R. Y. Storrs, Civilizing Capitalism: The National Consumers' League, Women's Activism, and Labor Standards in the New Deal Era (Chapel Hill, 2000).

${ }^{13}$ Patricia Cleary, Elizabeth Murray: A Woman's Pursuit of Independence in EighteenthCentury America (Amherst, 2000); Nikki Mandell, The Corporation as Family: The Gendering of Corporate Welfare, 1890-1930 (Chapel Hill, 2002); Daniel Delis Hill, Advertising to the American Woman, 1900-1999 (Columbus, Oh., 2002).

${ }^{14}$ Clark Davis, Company Men: White-Collar Life and Corporate Cultures in Los Angeles, 1892-1941 (Baltimore, 2000); Jeffrey Hornstein, A Nation of Realtors: A Cultural History 
local studies, Abbe Karmen, who has studied the real-estate industry, and Katina Manko, who has explored the business of sales-add to the fund of information through detailed and careful recovery of historical data. ${ }^{15}$ For the most part, these are national histories firmly situated within traditional approaches to business history that focus on firms, industries, or business types. In contrast, what I am calling "comprehensive histories" erase the boundaries between such disciplines as labor, business, or gender history by posing social, economic, and cultural questions that link business activity to a broad range of social experience.

Autobiographical narratives are a useful place to begin, since they constitute a persistent and effective business history genre. Businesswomen's autobiographies, a recent phenomenon that has yet to be explored by historians, constitute a rich area for research, in terms of both the autobiographies themselves and what they represent. Most have been written by women who have held executive positions in service industries. ${ }^{16}$ Given women's dominance in services, it is not surprising that their gains at the managerial and executive levels have come in communications, financial services, entertainment, public utilities, and trade. The earliest female managers and executives achieved their positions by asserting a unique "feminine style" of management that relied on women's connection to service. ${ }^{17}$ These autobiographies demonstrate the strong impact of occupational sex segregation on the evolution of women's roles and expectations, which have been shaped by their involvement in the service sector.

Businesswomen's autobiographies use a traditional business narrative, in which a plucky individual perseveres against the odds, ultimately to achieve success. Their stories are distinctive, in that "success"

of the Twentieth-Century American Middle Class (Durham, 2005); Roger Horowitz, ed., Boys and Their Toys? Masculinity, Class, and Technology in America (New York, 2001); Stephen Norwood, Strikebreaking and Intimidation: Mercenaries and Masculinity in Twentieth-Century America (Chapel Hill, N.C., 2002).

${ }^{15}$ Susan Ingalls Lewis, "Women in the Marketplace: Female Entrepreneurship, Business Patterns, and Working Families in Mid-Nineteenth-Century Albany, New York" (Ph.D. diss., State University of New York, Albany, 2003); Edith Sparks, "Married Women and Economic Choice: Explaining Why Women Started Businesses in San Francisco between 1890-1930," Business and Economic History 28 (Winter 1999): 287-301; Abbe Lynn Karmen, "Closing Costs: Gender and the Professionalization of Real Estate Sales in the United States" (Ph.D. diss., University of Delaware, 2001); Katina Lee Manko, “Ding Dong! Avon Calling!': Gender, Business, and Door-to-Door Selling, 1890-1955" (Ph.D. diss., University of Delaware, 2001).

${ }^{16}$ See, for example, Mary Cunningham, Power Play: What Really Happened at Bendix (New York, 1984); Lois Kathryn Herr, Women, Power, and AT\&T: Winning Rights in the Workplace (Boston, 2003); Ann Hopkins, So Ordered: Making Partner the Hard Way (Amherst, Mass., 1996); Estée Lauder, Estée: A Success Story (New York, 1985); and Dawn Steel, They Can Kill You but They Can't Eat You: Lessons from the Front (New York, 1993).

${ }^{17}$ Angel Kwolek-Folland, Engendering Business: Men and Women in the Corporate Office, 1870-1930 (Baltimore, 1994); Sharon Hartman Strom, Beyond the Typewriter: Gender, Class, and the Origins of Modern American Office Work, 1900-1930 (Urbana, Ill., 1992). 


\section{Angel Kwolek-Folland / 434}

is more often defined as winning lawsuits and changing corporate cultures than as earning huge salaries or managing a corporate crisis. ${ }^{18}$ These are histories of the mid-twentieth-century service sector that focus on corporate social activism, defenses of women's right to inhabit executive positions in service-based industries, and commentaries on the failure of the management "rationalism" that prevailed in the $1970 \mathrm{os}$. For example, Lois Kathryn Herr describes her experience of filing a federal affirmative-action case against her employer, AT\&T, which led to the transformation of the gender makeup of the company's labor force. ${ }^{19}$ Her story is an example of how the second wave of the women's movement that took place in the 1970 s initiated personal and institutional change in the culture of work at a major U.S. corporation. In Herr's book, the autobiographical tradition shifts away from its usual emphasis on individual business success to become a form that historians would recognize as an account that combines labor, social-movement, and corporate organizational history. Herr narrates her story as a case of insider activism for institutional change. Mary Cunningham's story of her actions as a Bendix executive provides a corrective to the usual explanation that women achieve corporate success by having sex with their male bosses. Ann Hopkins's account of her high-profile discrimination lawsuit against the accounting firm Price Waterhouse illustrates both the sex biases of corporate culture in the service industries and women's ability to use the court system to effect change. ${ }^{20}$

These autobiographies blur the distinctions among labor, women's, and business histories, and between women's occupations in the services and their role in corporate management, using the methodology of women's history. One strategy, exemplified in the autobiographies, connects women's role in organizational change to external social movements, particularly the second wave of the women's movement, which had an impact on corporate organizations in the $1970{ }^{21}{ }^{21}$ Another links women's experience to pervasive assumptions about gender that regard all women's work as functioning within a privatized context. Hopkins's story of her discrimination lawsuit, for example, revolves around her male colleagues' insistence that she dress and act "more like a woman." These autobiographies are not "great woman" histories that identify individual action as the engine of change but, rather, are examples of how

${ }^{18}$ Cunningham, Power Play; Herr, Women, Power, and AT\&T; Hopkins, So Ordered.

${ }^{19}$ Herr, Women, Power and AT\&T.

${ }^{20}$ Ibid.; Cunningham, Power Play; Hopkins, So Ordered.

${ }^{21}$ See, for example, Nancy MacLean, "The Hidden History of Affirmative Action: Working Women's Struggles in the 1970s and the Gender of Class," Feminist Studies 25 (Spring 1999): 43-78; and Mary Fainsod Katzenstein, "Feminism within American Institutions: Unobtrusive Mobilization in the 1980s," Signs 19 (Autumn 1990): 27-54. 
women in organizations have used external social forces to add another dimension to business structures, rules, and expectations.

The area of traditional business history that encompasses the history of the firm-entrepreneurship, small business development, and proprietorship-has been a particularly fruitful place for comprehensive histories that address the gender of the service sector. This literature normally focuses on sector development, government-business relations, firms, or the importance of the talented individual. Further, it often treats small business, entrepreneurship, and large corporations as distinct phenomena. Comprehensive histories that discuss business formation as a function of gender, in contrast, cover a range of topics: the impact of gendered ideology on corporate development, which is the subject of my own Engendering Business; the complex class stratifications of work and consumption described by the late Susan Porter Benson in Counter Cultures; the relation between gender and business niches ably articulated by Wendy Gamber in The Female Economy and The Boardinghouse in Nineteenth-Century America; and the persistence of the small businesses Andrea Tone analyzes in Devices and Desires. These authors explore how business forms and expressions are interconnected with gender by raising questions based in labor history, the history of technology, the history of consumption, and the social history of class and ethnicity. ${ }^{22}$

Andrea Tone's study of birth control in the United States is a good case in point. The service sector encompasses birth control, but, for most of our history, birth-control products and services have been illegal, produced and sold by nonspecialists, and dominated by female midwives and proprietors, and thus have been beyond the purview of economists and business historians. Tone brings the subject into business history by examining the nature of product supply and demand and the relation between firms and society. ${ }^{23}$ The birth-control industry, as Tone describes it, has been shaped by a number of players operating in complex national and local political and economic contexts. There were persistent and committed urban and rural consumers who kept the market strong and growing, despite the illegality of the products after 1873 . Production and sales continued to rely on small-scale entrepreneurs, even as corporate giants like Goodyear, Firestone, and Sears Roebuck entered the competition. Congress proved unwilling to supply the agents needed by the federal postal service to enforce the 1873 Comstock law,

${ }^{22}$ Kwolek-Folland, Engendering Business; Benson, Counter Cultures; Wendy Gamber, The Female Economy: The Millinery and Dressmaking Trades, 1860-1930 (Urbana, Ill., 1997), and The Boardinghouse in Nineteenth-Century America (Baltimore, 2006); and Andrea Tone, Devices and Desires: A History of Contraceptives in America (New York, 2001).

${ }^{23}$ Tone, Devices and Desires. 
effectively killing its regulatory functions, at least over major producers. Finally, the court system remained reluctant to enforce a federal law for fear of upsetting the delicate balance between state and federal regulatory powers.

Tone's comprehensive approach reveals the arbitrary historiographical division between the small proprietorships and entrepreneurial endeavors women engaged in when selling birth-control techniques and technologies, conceptualized as "services," and the "big business" of manufacturing the same technologies engaged in by Goodyear and Sears. The former have not been included in business history, while the latter are its quintessential subjects. ${ }^{24}$

Consumerism emerged in the 1980 os as an especially important location for gendered business history and, in the historiography of the United States at least, scholars have studied the expansion of service industries predominantly in the context of the growth of consumption. Consumerism, advertising, and consumption have combined to represent the single largest publishing area in U.S. gender business history since 1995. It is one of the few fields that incorporates women directly into the research base, in this case as consumers or as providers of services to consumers. The historical process of the feminization of consumption, beginning in the eighteenth century, has at least two dimensions. On the one hand, U.S. women of all classes in the nineteenth century gained more say about household purchasing decisions, and they justified their continuing involvement in businesses that provided goods and services by staking a claim to special skills or knowledge. On the other hand, the cultural meaning of the act of consuming-of choosing from among goods and services and then displaying and using them-was devalued economically, because it was seen as female. ${ }^{25}$ Echoes of both dimensions continue to reverberate in the current feminization of the service sector and in the historiography of business.

While business historians have willingly explored consumption, even tracing the globalization of a consumer economy to the sixteenth cen-

\footnotetext{
${ }^{24}$ Since the publication of Alfred D. Chandler Jr.'s Visible Hand: The Managerial Revolution in American Business (Cambridge, Mass., 1977), big business has been a central element of business history. On Chandler's contribution, see Richard R. John, "Elaborations, Revisions, Dissents: Alfred D. Chandler Jr.'s The Visible Hand after Twenty Years," Business History Review 71 (Summer 1997): 151-200.

${ }^{25}$ On the devaluation of women's work, including consumption, see the introduction to this issue. Jeanne Boydston, in Home and Work: Housework, Wages, and the Ideology of Labor in the Early Republic (New York, 1990), discusses what she terms the "pastoralization of housework," the process by which domestic labor was devalued in both the home and the marketplace as wages rose in economic importance. See also Elizabeth White Nelson, Market Sentiments: Middle-Class Market Culture in Nineteenth-Century America (Washington, D.C., 2004); and Laura Byrne Pacuet, The Urge to Splurge: A Social History of Shopping (Toronto, Ont., 2003).
} 
tury, only recently have they begun to pay attention to the impact of women's work and purchasing habits on the development of international business and the world economy. ${ }^{26}$ Patricia Cleary's recent study of Elizabeth Murray, as well as Linda Sturtz's work on women of property in eighteenth-century Virginia, for example, reveal female merchants and agriculturalists operating at the nexus of the trans-Atlantic economy in the early modern period. ${ }^{27}$ Kristin Hoganson's recent treatment of domestic consumerism in the United States emphasizes the impact of American middle-class women's consumption on globalization. ${ }^{28}$ She argues that what she terms "cosmopolitan domesticity"middle class women's inclination to decorate their homes with foreign goods-played an important part in economic and cultural globalization at the turn of the twentieth century. ${ }^{29}$ Hoganson's work builds on the work of feminist economists, sociologists, and anthropologists who have been dissecting the gender dimensions of the global economy for over thirty years. Scholars such as Teresa Amott, Esther Boserup, Cynthia Enloe, Julie Matthaei, June Nash, Helen Safa, and, more recently, Jo Doezema, Carla Freeman, Karen Hansen, and Kamala Kempadoo, have charted the intimate connections between corporate globalization and gender in countries around the world. ${ }^{30}$ Their critiques suggest that women, both as workers and as consumers, have been the backbone of the service sector throughout the past 250 years of globalization, and that the expansion of the female labor force has been a factor that has driven corporate growth internationally since at least the $1960 \mathrm{~s}$.

These comprehensive approaches expand the purview of business history, pushing it outward from the firm in order to survey the larger

\footnotetext{
${ }^{26}$ Robert J. Holton, Globalization and the Nation-State (New York, 1998); Roland Robertson, "Globalisation or Glocalisation?" Journal of International Communications 1, no. 1 (1994): 33-52; Boaventura de Sousa Santos, "Toward a Multicultural Conception of Human Rights," in Moral Imperialism: A Critical Anthology, ed. Berta Esperanza Hernández-Truyol (New York, 2002), 39-60; and Jan Aart Scholte, Globalization: A Critical Introduction (New York, 2000).

${ }^{27}$ Cleary, Elizabeth Murray; Sturtz, Within Her Power.

${ }^{28}$ Kristin Hoganson, Consumers' Imperium: The Global Production of American Domesticity, 1865-1920 (Chapel Hill, 2007).

${ }^{29}$ Ibid., 57.

${ }^{30}$ See, for example, Carla Freeman, "Is Local: Global as Feminine: Masculine? Rethinking the Gender of Globalization," Signs 26 (Summer 2001): 983-1039; Amott and Matthaei, Race, Gender, and Work; Ester Boserup, Women's Role in Economic Development (New York, 1970); Cynthia Enloe, Bananas, Beaches, and Bases: Making Feminist Sense of International Politics (Berkeley, 1990); Carla Freeman, High Tech and High Heels in the Global Economy: Women and Pink-Collar Identities in the Caribbean (Durham, 1999); Karen Hansen, Salaula: The World of Secondhand Clothing and Zambia (Chicago, 200o); Kamala Kempadoo and Jo Doezema, eds., Global Sex Workers: Rights, Resistance, and Redefinition (New York, 1998); June Nash, ed., Crafts in the World Market: The Impact of International Exchange on Middle American Artisans (Albany, 1993); and Helen I. Safa, The Myth of the Male Breadwinner: Women and Industrialization in the Caribbean (San Francisco, 1995).
} 
society, and also inward so as to encompass the social nature of the firm. The first step is recognizing that the categories themselves-sectors, firms, management, labor, consumption, production-are the outcome of gender norms. Political philosopher Nancy Fraser identified one fact that is critical to understanding Western economies: "women's work," no matter where it occurs, is held within the possibilities and constraints of the private household. ${ }^{31}$

\section{Case Study: Households and the Service Sector}

To explore in more detail the relation between women's work, the social and economic value of services, and business history, I will turn now to a case study on the conceptualization of "domestic work" that has implications for the service sector and the history of business. In particular, I will explore some of the ways that household labor can be redefined to place the service sector more firmly in the context of business history by looking at household economic interchanges, using census and other data gathered for the period from 1870 to 1880 for the town of Lawrence in Douglas County, Kansas. ${ }^{32}$

The formative period of statistical collection and modern census methodologies coincided with the maturation in the West of liberal capitalism and the ideology of separate spheres in the 1870 os and 1880 s. By the 1880 s, both federal and state censuses incorporated detailed reporting on economic categories such as the dollar value of manufacturing and agricultural production and the age, race, and gender of the employed population. ${ }^{33}$ Whatever the particulars, however, census economic data privileged the public economy. Whether state or federal, the census or-

${ }^{31}$ See the introduction to this issue, especially the discussion of Nancy Fraser's "What's Critical about Critical Theory? The Case of Habermas and Gender," New German Criticism 35 (Spring/Summer 1985): 107.

${ }^{32}$ Lawrence is on the state's eastern border. It has an important place in the political and social history of the late nineteenth century, and in the 1870 s it was moving from the frontier stage to consolidation as an urban agricultural center, the most common town form in the nineteenth-century United States. For the most part, its demographic profile is typical of towns under 10 , ooo in this period.

${ }^{33}$ The United States federal constitution mandated that a national census be taken every ten years, beginning in 1790 . State censuses, when taken, occurred in mid-decade and tended to adopt the same categories and in many cases the same coverage as the federal census, which set the agenda for what was counted in any given decade. Both federal and state censuses shifted their interests over time, depending on political debates as varied as concern over the sources of immigration, miscegenation in a postslavery society, urban infrastructure problems (such as water and sewer systems), the value of natural resources, and the growth of a female wage-labor force. The most useful work on the social evolution of the federal census is Margo J. Anderson's The American Census: A Social History (New Haven, 1988), especially ch. 4. See also U.S. Department of Commerce, Bureau of the Census, Historical Statistics of the United States, Colonial Times to 1970, pt. 1 (White Plains, N.Y., 1972), series G-495-581 and G582-601, 322. 
ganized economic data by industries and products, not by consumption, domestic services, reproductive rates, or racial divisions. The censuses focused on industrial and agricultural job categories taken from production sectors, rather than on degrees or types of skills workers possessed; levels of capitalization; race; or household economic contributions, such as savings, in-kind trading, or maintenance (cooking, cleaning, child care). Even though enumerators collected employment and other data by households, making the family the basic unit rather than individuals or businesses, the aggregate data assumed that meaningful economic activity occurred only in nondomestic, nonresidential production sites. Families were economic units headed by male breadwinners, but economic events occurred only beyond the family's front door.

The 1870 federal census, for example, which was the first to use "modern" categories, divided the occupational structure into positions in trade, transportation, manufacturing, mechanics, personal services, agriculture, and the professions. ${ }^{34}$ These categories were organized according to production and products, except for that of the professions, which was based on skill and educational investment. Given the divisions of wage labor based on gender and race in capitalist economies, these categories automatically benefited the "public" sector and whites, and they disadvantaged the "private" sector and "coloreds." Male workers were present in every category, whereas women were not. The census categories by default consigned women disproportionately to "personal services" and ignored household-oriented work or production altogether, except where it was available commercially. In contrast, in both law and custom, preindustrial society valued women's skills in domestic household production and consumption. Jeanne Boydston has argued that the advent of cash wages devalued women's household labor because it was not directly a part of the waged, public economy. ${ }^{35}$

Federal and state censuses in the nineteenth century both demonstrated and reinforced this shift from an integrated to a bifurcated understanding of economic activity. Anyone using census information to calculate occupational trends, the value of women's labor, or demographic changes in women's economic activity, begins with data that is skewed to the public-private, race-neutralized distinctions of neoclassical economics. Yet those distinctions are built on logical flaws and hierarchical assumptions that undervalue certain forms of economic activity and place a premium on others. ${ }^{36}$ One could approach these problems of

${ }^{34}$ The overall categorization has had a remarkable longevity. "Service sector" industries, for example, have remained constant since the 1870 . See, for example, U.S. Census Bureau, Current Business Reports SAS/03, Service Annual Survey: 2003 (Washington, D.C., 2005).

${ }^{35}$ Boydston, Home and Work.

${ }^{36}$ Fraser, "What's Critical about Critical Theory?" 107. 
definition and categorization from several directions. I have chosen for this discussion to concentrate on economic "interchanges," rather than on the production categories emphasized by the census, and I use the concept of "comparable worth" to explore those interchanges. This inquiry into the limitations of the census will suggest the inadequacy of the neoclassical economic dualism of public-private, which is the basis for the concept of the service sector, for positioning women's economic activities in business history.

"Comparable worth" correlates economic activities based on the kinds of personal interactions and levels of education, knowledge, and "capitalization" involved-the process-rather than on what is produced or definitions of "skill," which are drawn from the assumption that what men do is more economically potent than what women do. ${ }^{37}$ This concept asks us to note specifically both the social relations at the basis of work and the definitions of value. For example, women's household labor, when sold in the marketplace, has a legitimate, if unspecified, economic value. Thus, while cleaning or cooking might be a part of the "private" economy when performed without pay, when sold by a "domestic" or a "cook" it takes on a value related to the necessary levels of capitalization, knowledge, skills, and supervisory requirements. The federal census validates this notion by including commercial positions like "cook," "laundress," and "nurse" in the "personal service" category. As a whole, focusing on economic interchanges rather than on production has the effect of infusing the "public" economy with labor and products normally defined as part of the "private" economy, and undermining some of the masculinized, product-based hierarchies of the federal occupational census categories.

A consideration of economic interchanges offers two categories that are of particular interest to business historians: "proprietors" and the "self-employed." These most closely mimic the traditional business emphasis on the firm, entrepreneurship, and/or small businesses. The "proprietor" category describes those with their own businesses who were likely to hire employees; the "self-employed" label covers those who offered some sort of service or product but were less likely to employ others. In Lawrence in the 1870 , "self-employment" was apparently a female version of proprietorship. While men in Lawrence dominated the proprietor category (22.2 percent of the total number of employed men, as opposed to 4.1 percent of women), women dominated the "selfemployed" (32.4 percent of employed women, as opposed to 7.4 percent

${ }^{37}$ Sara M. Evans and Barbara J. Nelson, Wage Justice: Comparable Worth and the Paradox of Technocratic Reform (Chicago, 1989). 
of men).$^{38}$ The self-employed population tended to be women doing for pay (monetary or in-kind) what all women did within the household. This category included piano teachers, laundresses, nurses, peddlers, seamstresses, and washers, among others. Proprietors included merchants, milliners, restaurateurs, saloonkeepers, and boardinghouse keepers, among others. Proprietors' businesses were tied to place, and thus required fairly large capital investment in buildings and fixtures. Those who were self-employed were not similarly bound to a particular spot, and they needed little in the way of specialized training (except perhaps piano teachers). Proprietors fit the classic description of small businesses; the self-employed did not, yet they engaged in many of the same economic tasks and personal interactions as proprietors. Business historians have not had much to say about this large category of "self-employed" people, yet research in labor history suggests that it is closer to how such individuals saw themselves: not as "workers" or "laborers," but as people in charge of their own economic choices. ${ }^{39}$

One way to conceptualize the prevailing view of the "servant problem" so widely discussed by middle-class white women in the nineteenth century is to contrast their sense of domestics as hired servants with the assertion by a domestic or servant of her independence as a "self-employed" businesswoman. Domestics claimed the right to move from household to household seeking the best value for their services, whether they worked by the day or as live-in domestics. ${ }^{40}$ Numerous black women listed themselves in Lawrence city directories in the $1870 \mathrm{~s}$ as "domestics," advertising their availability as service providers. Ellen Austin, an African American washer, is listed twice in the 1875 Lawrence census: once as a "domestic" in a white family for whom she worked, and once as the head of a black household. Depending on who was responding to the census taker, Austin was either an "employee" in a white family or the self-employed head of her own family. ${ }^{41}$ Fannie

${ }^{38}$ Demographic data is drawn from the 1875 Kansas State manuscript census, Kansas State Historical Society (Topeka, Kansas) [hereafter KSMC], cemetery records, city directories, and other archival sources for Lawrence, Douglas County. I created a data set that includes 7,265 individuals.

${ }^{39}$ See, for example, Tera Hunter, To 'Joy My Freedom: Southern Black Women's Lives and Labors after the Civil War (Cambridge, Mass., 1997). On daily domestics as "selfemployed," see Elizabeth Clark-Lewis, Living In, Living Out: African American Domestics in Washington, D.C., 1910-1940 (Washington, D.C., 1994), esp. ch. 6.

$4^{\circ}$ On domestic service in the nineteenth-century, see Hasia Diner, Erin's Daughters in America: Irish Immigrant Women in the Nineteenth Century (Baltimore, 1983); Faye Dudden, Serving Women: Household Service in Nineteenth-Century America (Middletown, Conn., 1983); Katzman, Seven Days a Week; and Carol Lasser, "The Domestic Balance of Power: Relations between Mistress and Maid in Nineteenth-Century New England," Labor History 28, no. 1 (1987): 5-22.

${ }^{41}$ Ellen Austin, 1875 KSMC, nos. 1/23/24 and 1/310/332. 
Horton's diary entries suggest that live-in domestic Lu Wilson had her own ideas about how she should conduct her work, ideas that conflicted with Fannie's. Horton was the wife of a state senator, but, like most middle-class women in this period, she was familiar with all aspects of household labor and did much of it herself when necessary. Fannie's comment when Lu left their service-"good riddance"-attests that the domestic asserted her own mind. Nevertheless, she stayed for over a month and a half and received $\$ 13.75$ for her work: nearly fifty cents a day plus room and board, a decent return at the time. ${ }^{42}$

Horton's dismissive phrase suggests a more discursive approach to formulating the nature of women's household economic activity: tracing the personal interactions occasioned by that activity. Horton's financial diary demonstrates both the complexity of "job categories" in the household economy of the nineteenth century and the social and cultural constructions shading their meanings and interactions. While censuses used one category to refer to women who did general domestic work, Fannie applied eight different terms to the women who worked in her home: "servant," "servant girl," "girl," "woman," "hired girl," "errand girl," "serving woman," and "colored girl." She referred to male laborers as "Swede man," "Dane man," "colored man," or simply, "man." These men were the more casual laborers, either hired for a day or for a job. Fannie's "Dane man," for example, probably was N. C. Sonne, a forty-year-old Danish laborer who lived in the neighborhood. ${ }^{43}$ Other exchange relations had personal names: "Ellen Douglas," "Lu Wilson," "Miss Porter," "Gabe," "Watt," "Mr. Skein."

There are numerous ways to interpret the nomenclatural distinctions that cut through these relations. "Girl" and "woman" might refer to age, marital status, or to differences in skill or race. An "errand girl" was surely a more casual acquaintance and a more intermittent employee than "Ellen Douglas." Yet the focus on race evident in "colored girl" disappears in "Lu Wilson," who was also, as it happens, African American. To skilled artisans, employees who were more intimate with the family, or hired workers who lived in the neighborhood, Fannie accorded the privilege of names. James (or "Peter") Skein was a piano tuner whose services were needed frequently in the shifting humidity of Kansas's annual weather round. "Mrs. Dr. [Francena] Porter" advertised in the local paper as a specialist in "obstetrics and diseases of women." She sold Fannie herbal remedies, medical advice, and her nursing skills during a problem pregnancy. "Gabe" was an African American

${ }^{42}$ Household financial records, Mrs. James C. [Fannie] Horton Diary, Lawrence, Kansas, 1874, Horace Moore Collection, Kansas State Historical Society, Topeka, Kansas.

${ }^{43}$ N. C. Sonne, 1875 KSMC no. $1 / 253 / 270$. 
laborer who shook out heavy carpets during spring cleaning, among other tasks. Probably he also was a neighbor, as were the washerwomen who came one day a week. ${ }^{44}$ Ellen Douglas was a former servant who had moved to New York but returned for a visit and helped in the household during a crisis. Fannie paid her for her work, but she was also affectionately called "our old servant Ellen." 45 Miss M. H. Stockwell was a well-known local dressmaker who advertised her services in the city directory. She also played croquet at Fannie's house. ${ }^{46}$

The complex social and economic relations of the fictional Aunt Hager Williams also are instructive. Aunt Hager is the pivotal character in Langston Hughes's autobiographical novel Not Without Laughter, which depicts life with his grandmother in early-twentieth-century Lawrence. The size, shape, and relative prosperity of Hagar's household are reflected in actual African American households in Lawrence during this period. Hager did the washing for six families each week, and her daughter worked as a cook fourteen blocks away in a white household. In addition to these interactions, Hager's near neighbors, black and white, knew her as a skilled and sympathetic nurse and welcomed her into their homes for these intimate services. As Hager worked in her yard, she chatted with another black woman-a peddler making her rounds-and negotiated with a local black laborer, stopping him as he drove his wagon through the alley. Hager's orientation to her local neighborhood was through her front door to her white neighbors across and down the street, and from her back alley and side yard to other African Americans. She sent her grandson Sandy downtown with cash to purchase thread or flour or to the homes of her customers with their laundry. No interchange was devoid of personal connection, social expectations, and self-evaluation. In response to a friend's comment that Hager's work was widely respected by her customers, Hager proudly observed, "I reckon white folks does think right smart of me." 47

As these examples make clear, status expectations, local knowledge, racial and class distinctions, and personal friendships colored domestic economic interactions. The service sector was not simply an aspect of public commerce; it also emerged from, and remained central to, the private, domestic economy and social relations. Students of labor relations, business, and the modern corporation have become intrigued by

\footnotetext{
${ }^{44}$ In this period, Lawrence's residential neighborhoods were racially integrated, although by the mid-1880s clear class distinctions were emerging.

${ }^{45}$ Horton diary, 15 Feb. 1874 .

${ }^{46}$ Horton diary, 16 July 1874 . See also, James Skein, $1875 \mathrm{KSMC}$ no. $2 / 1 / 1$; M. H. Stockwell, 1875 KSMC no. 4/63/68; and Lawrence City Directory for 1873-74 (Lawrence, 1874) [hereafter LCD].

${ }^{47}$ Langston Hughes, Not Without Laughter (New York, 1995), 139. The novel was first published in 1930 but is set at the turn of the century.
} 


\section{Angel Kwolek-Folland / 444}

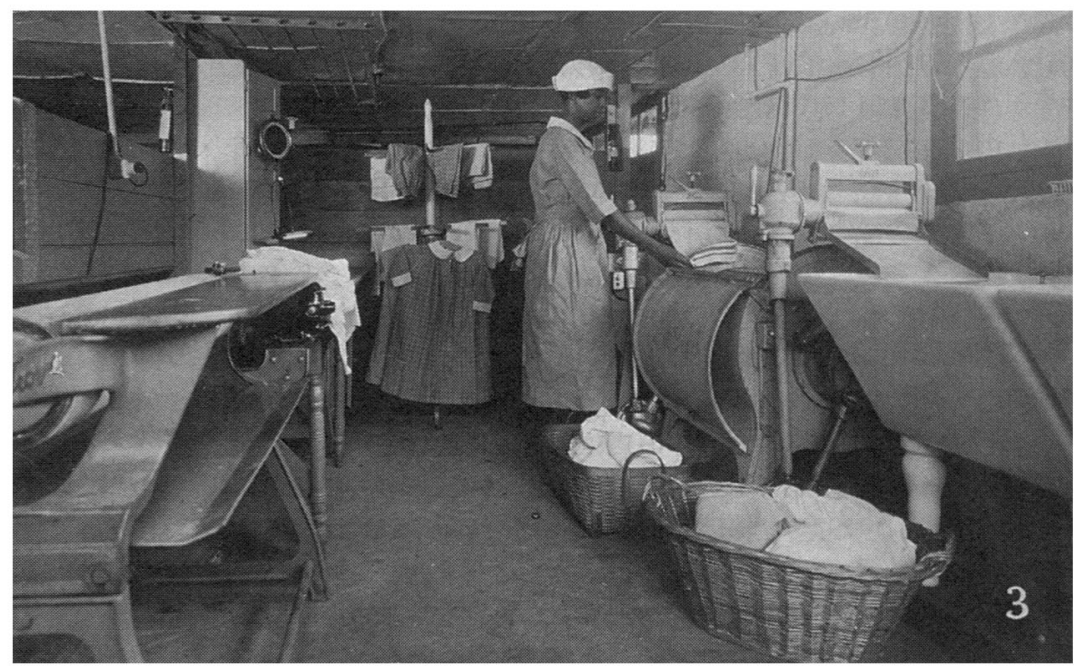

Portrait of a woman running a dish towel through a mangle in the laundry room of the Applecroft Home Experiment Station, ca. 1913. (Courtesy of the Schlesinger Library, Radcliffe Institute, Harvard University.)

the amalgam of social and cultural behaviors weaving their way through organizations. ${ }^{48}$ Cultural anthropologists and specialists in management styles have noted that the absence of this social infrastructure would seriously jeopardize the modern corporation's ability to produce and sell products. The history of labor relations in manufacturing and the marketing of public utilities point to the insistent presence of social and cultural factors in creating products and markets. ${ }^{49}$ Housewives like Fannie Horton and Aunt Hager engaged on a daily basis in elaborate and compound socioeconomic events, much like the ones that structured shop floors, department stores, insurance and banking offices, and other public economic arenas.

Laundry work is a useful example of the economic, social, and technological complexity of household services, as it reveals how household services functioned as a business activity. Washing clothing and linens

${ }^{48}$ Sharon Zukin and Paul DiMaggio, eds., Structures of Capital: The Social Organisation of the Economy (Cambridge, 1990); "Corporate Culture," a special issue of Social Text 44 (Fall/Winter 1995); Benson, Counter Cultures; Kwolek-Folland, Engendering Business; and Ava Baron, ed., Work Engendered: Toward a New History of American Labor (Ithaca, 1991).

${ }^{49}$ Mark Rose, Cities of Light and Heat: Domesticating Gas and Electricity in Urban America (University Park, Md., 1995); Sanford M. Jacoby, Modern Manors: Welfare Capitalism since the New Deal (Princeton, 1997); and Richard Edwards, Contested Terrain: The Transformation of the Workplace in the Twentieth Century (New York, 1979). 
was one of the most widespread household economic exchanges in the period before commercial laundries, involving networks of production and consumption that began with mixing noxious chemicals and ended with home delivery. ${ }^{5}$ Buyer and seller engaged in face-to-face negotiations over price and quality. Several women did Fannie Horton's washing and ironing, including forty-five-year-old "Ronnie Brown," who is listed in the census as a "washer." 51 Usually washers took laundry to their own homes for processing. Aunt Hager, for example, sent young Sandy to her customers' houses to pick up laundry; she then washed the items outside and hung them on the line to dry in good weather. Her work thus was highly visible to other neighborhood residents. On occasion, as occurred sometimes in the Horton household, washers also did the work on the customer's premises. ${ }^{52}$

Laundry work was necessary but universally hated. It also was exceedingly complex, and before the 1880 s "labor-saving" devices such as wringers or gasoline irons barely relieved that complexity. ${ }^{53}$ In our world of commercial dry cleaners, home washing machines, and packaged cold-water detergents, it is difficult to envision the high level of skill and knowledge needed to clean even the simplest items. Some fabrics had to be sponged with flammable kerosene, a dangerous procedure. Trade catalogues and household advice books from the 1840 os onward chronicle the knowledge of elementary chemistry, the inventiveness, and the sheer physical stamina involved in laundering. The Home Cook Book of 1874 contained recipes for washing fluid, starch, and "Javelle water for mildew stains" that involved-not all in the same recipeunslacked lime, chloride of lime, sal soda (sodium carbonate, used to make soap sudsy, producing the effervescent action that bubbles out dirt), potash (potassium carbonate, made by leaching wood ashes, and then calcining or purifying the lye by applying heat), sugar, butter or lard, and rainwater (which was free of unpredictable mineral impurities). These various ingredients were boiled, cooled, mixed, boiled again, and finally bottled. ${ }^{54}$

\footnotetext{
${ }^{50}$ Before commercialization moved laundering to specialized facilities (by the 1890 s in major urban areas), washing took place in residential neighborhoods, inside and outside of domestic dwellings. See Arwen Mohun, Steam Laundries: Gender, Technology, and Work in the United States and Great Britain, 1880-1940 (Baltimore, 1999).

${ }^{51}$ Lu Wilson, Household financial records, Horton diary, n.p.; Ronnie Brown, 6 May 1874 , and Maria Brown, 1875 KSMC no. 3/279/304.

${ }^{52}$ Fannie's diary notes expenditures for washing-machine parts and repairs, indicating that she possessed some sort of washing or wringing machine. This was unusual in 1875 , and no doubt made it easier to do the laundry on her premises, once the washer had mastered the machine. See entries for "Cash Account May 1875," Horton diary.

${ }^{53}$ On household technology, see Ruth Schwartz Cowan, More Work for Mother: The Ironies of Household Technology from the Open Hearth to the Microwave (New York, 1983); and Susan Strasser, Never Done: A History of American Housework (New York, 1982).

${ }^{54}$ The Home Cook Book (Chicago, 1874), 376, 377, 379.
} 


\section{Angel Kwolek-Folland / 446}

Once these cleansing materials had been prepared, washers used them in a complex procedure of soaking, scrubbing, beating, soaking, boiling, rinsing, bluing, rinsing, starching, wringing, stretching, drying, and ironing (with ironing sleeves, pleaters, ribbon rollers, curling irons, and flat irons, to name just a few of the specialized tools then in use). Fabrics whose colors bled easily, such as calico or silk embroidery, had to be handled differently from wool, as did wool from linen, linen from cotton, flannel from muslin, and lace from chintz. The varied lore of laundry also suggested myriad remedies to whiten without fading, keep dark colors dark, or brighten colors without destroying the fabric. Laundresses-or insolvent housewives forced to do their own laundrycould add, depending on the problem, boiled rice, gum camphor, pepper, mucilage, ammonia, potatoes, black tea, or milk. Blankets and quilts required different types of washing and drying to prevent tearing and stretching. Lace curtains were not to be ironed at all, but their traceries were basted in place, patted with soap, boiled, rinsed, blued, dipped in mucilage, and dried in the sun. ${ }^{55}$ Small wonder that women who had the means happily paid other women for these services.

Most women who did laundry for pay also made their own soap in fire pits in their yards and invested in specialized tools or ingredients. Children were an economic boon for washers: they could tote, run errands, and make deliveries. Both nationally and in Lawrence, washing clothes was African American women's entrepreneurial niche. ${ }^{56}$ Only three white women in the 1875 census were listed as "washers"; one of these was a European immigrant. Washing was almost overwhelmingly an older woman's job: the average age of African American washers in 1875 was 38.6 , and in 1885, 43.4; Jane Scruggs, like Hager Williams, was in her 70 s. $^{57}$ The older age of washers may have reflected their need and/or desire to work at home in order to supervise dependents, while the presence of dependents increased their earning power.

Washing was an economic mainstay of many female-headed African American households, evidence of both the lack of access to other economic niches and the poor earning power of black men. In Lawrence,

${ }^{55}$ See, for example, S. H. Burt, The Universal Household Assistant, or What Everyone Should Know: A Cyclopedia of Practical Information (New York, 1885), 29-108, 158, 268, 483-85; The Home Messenger Book of Tested Receipts (Detroit, 1873); Marion Holmes, How to Cook (Chicago, 1883), 337; and The Housewife's Library: (Many Volumes in One) Furnishing the Very Best in All the Necessities (Philadelphia, 1883), 631-32.

${ }^{56}$ Hunter, To 'Joy My Freedom.

${ }^{57}$ Lily Barnes, 1875 KSMC no. 1/163/176. Scruggs was born in Virginia in 1794, no doubt as a slave. Cemetery records from Lawrence document her death in 1884 , at ninety years of age. Her lifetime spanned the creation of the Constitution, the end of slavery, and the birth of modern America. Jane Scruggs, KSMC no. 5/111/116, Oak Hill Cemetery, permit no. 2708, lot 1222. 
seventy-seven black women in 1875 , and forty-four black and mulatto women in 1885 , were washers. Sixty-six percent of black washers in 1875 and 57 percent in 1885 were heads of households. About a third of the remaining washers lived in households headed by a washer. In 1875 , 69 percent (fifty-three) of these female heads of households had dependents, several of them boarders or other unrelated persons. Patsey Felton supported four children under the age of twelve, three of whom had different last names. ${ }^{8}$ One household sheltered two children, three male laborers, two unrelated women who were washers, and a female cook, for a total of eight people. (The average household size among washers was four.) In fact, in 1875, 56 percent of African American women washers in Lawrence claimed property, registering an impressive mean of $\$ 470$ in real and $\$ 63$ in personal property. Washing was the most lucrative work available to African American women in this period.

Scholars have reconstructed many aspects of domestic household service, especially the complex relations between householders and servants. For the most part, these reconstructions emphasize servants' positions as laborers within a household and further the notion that the availability of servant labor freed middle-class mistresses from the burdens of work while promoting housewives' roles as "supervisors" of domestic help. ${ }^{59}$ However, some historians have pointed out that many domestics were self-employed and that housewives worked alongside the women they "supervised." Perceived as a labor-management issue, the relation between housewives and servants assumes all the trappings of economic interchange: determining the value of goods and services, contracting for those products, establishing credit and skill relations, and negotiating the necessary differences between the expectations of labor and management. The women and girls who served as domestics or servants brought labor problems, workplace struggles over wages and hours, and entrepreneurial independence directly into the private family. The presence of a servant turned a housewife into an employer, manager, or contractor in a world of shifting economic and social values. ${ }^{60}$

Yet pure economic considerations rarely ruled the choices of housewives and servants. Housewives evaluated domestics on how they performed their duties and on their personal characteristics-precisely the same sort of criteria used by corporate managers. ${ }^{61}$ Women who offered domestic services evaluated employers on the basis of working conditions, the degree of autonomy and respect accorded their skills,

${ }^{58}$ Patsey Felton, 1875 KSMC no. 6/85/88.

${ }^{59}$ See, in particular, Dudden, Serving Women, 155-92. Dudden constructs "supervision" as noneconomic activity, in fact as the antithesis of production.

${ }^{60}$ Lasser, "The Domestic Balance of Power"; and Katzman, Seven Days a Week. 


\section{Angel Kwolek-Folland / 448}

and the level of wages or in-kind remuneration. ${ }^{62}$ In any event, domestic workers had a fine-tuned sense of what employers could reasonably expect of them and what sort of relations they could demand as selfemployed day workers or live-in servants. Local African American newspaper editor John L. Waller reported in 1883 that there was "talk of calling a meeting of the laboring women of color, in Lawrence, in order to bring about a higher compensation for their work." A successful strike by washerwomen in Atlanta a few years earlier may have served as inspiration. Waller's report was sympathetic, citing $\$ 0.75$ per day as wages too low to "feed a bird, much less a hard working woman." 63

Women's economic activity within the household in this period often shaded into the provision of commercially available services and products of the type recognized by census categories. The labor involved in boarding relatives or strangers, for example, turned women's domestic skills, such as food preparation and cleaning, into commercial resources for the household economy. As Wendy Gamber has noted, boarding was simultaneously a small business and an extension of domestic labor, and those who kept boarders were well aware of the tensions between domesticity and business encapsulated in the boardinghouse economy. ${ }^{64}$ Fannie Horton's mother, Isabel Weld, ran a boardinghouse in Lawrence where Fanny, realizing what was in fact a classic boardinghouse romance, met her future husband, James Horton. Insurance agent J. N. Vanhoesen lived with his wife, their three-year old child, a Swedish domestic servant, a black laborer, and a bookkeeper, who probably worked for him. A portion of the bookkeeper's wages was withheld in payment for his board and room; the labor of Mrs. Vanhoesen and the servant amounted to an in-kind contribution to his livelihood and to the capitalization of the insurance agency. Some women treated their residences as studios open to the paying public. Miss Lillian Bell and the young widow Fannie Blish Robinson, for example, were only two of hundreds of nineteenth-century women and girls who gave piano lessons in their parlors. Others taught elocution, painting, singing, and languages at home. ${ }^{65}$

\footnotetext{
${ }^{61}$ Kwolek-Folland, Engendering Business.

${ }^{62}$ For example, an advertisement placed by a prospective domestic in the Daily Kansas Tribune [hereafter DKT], 6 Jan. 1874, 2, which ran for several weeks.

63 "Important Business," Western Recorder, 28 June 1885, 2; Hunter, To 'Joy My Freedom, 74-97. Waller encouraged further reports of their collective action, but either the women did not meet or they were not interested in publicizing their efforts, as the paper had no follow-up report.

${ }^{64}$ Gamber, The Boardinghouse.

${ }^{65}$ Jacob Oesch, KSMC no. 2/26/29; J. N. Vanhoesen, KSMC no. 1/51/52; Miss Coathope, DKT, 4 July 1874, 4; Lillian Bell, Lawrence Daily Journal, 16 Jan. 1885; and Miss Ferris, 24 Mar. 1885.
} 
Housewives sometimes took advantage of the occupational sex segregation of the service sector to maximize returns on household production. Elizabeth Martin ran the family's boarding house while her husband, Henry, looked after their saloon. Women kept the books for the family store, worked behind the counter at the corner grocery, or provided in-kind services in family-owned restaurants or other establishments operated out of their dwellings. ${ }^{66}$

Thousands of nineteenth-century women like Fannie Horton and Aunt Hager managed servants or workforces of family members, bargained on back porches or in back yards for goods and services, augmented household incomes with garden produce, and sold skills in local neighborhood markets composed of other housewives. Reconfiguring household economic activities as part of the public economy, whether through revamped census categories or simply through a shift of perspective, suggests the importance of these activities both to women themselves and to our understanding of the relevance of the service sector to the history of business.

\section{Conclusion}

Services have not been a central topic of business history for a number of reasons, some of them related to the project of business history itself and its focus on the firm and entrepreneurship, some related to subject divisions in historical research, some to a disciplinary blindness about gender, and some to the nature of available data. However, as the comprehensive histories and the case study of nineteenth-century Lawrence analyzed here suggest, services can provide an invaluable link between traditional business history interests and the social relations at the center of economic exchange. The service sector is a subject that should be central to the history of business. Business historians should become sensitive to the gendered aspects of proprietorship, social change, institutional functionality, the sectoral divisions of the economy, and the personal and social relations at the basis of economic interchange.

Shared notions about gender created business niches for women as entrepreneurs, workers, managers, and proprietors, even as they led to the attachment of the "service" label to women's business participation; the idea of "service" reinforced differences of class and race and

\footnotetext{
${ }^{66}$ DKT, 10 Jan.; LCD, 143; Katja Rampelmann, "Small Town Germans: The Germans of Lawrence, Kansas from 1854 to 1918 " (unpublished master's thesis, University of Kansas, 1993), 24, 54; DKT, 1 Jan. 1874, 2. The ad appeared at least once a week in the 1870 s.
} 
strengthened the idea of women's role as one combining consumption and production. Small proprietors and households violate the boundaries created by the neat divisions of economic sectors and census categories to engage in the same kinds of economic interchanges found in the public economy. Writing the business history of the service sector will mean pursuing some combination of local, national, and international studies that are attuned to lived experiences as well as large-scale economic factors. 